\title{
FAJAR NUSANTARA MOVEMENT (GAFATAR) HERESY IN THE PERSPECTIVE OF INDONESIAN ULEMA COUNCIL (MUI)
}

\author{
Prof. Dr. Titik Triwulan Tutik ${ }^{* 1} 凹$ iD \\ ${ }^{* 1}$ S.H, M.H, Faculty of Sharia and Law Sunan Ampel State Islamic University, Surabaya, Indonesia
}

DOI: https://doi.org/10.29121/granthaalayah.v9.i2.2021.3382



Article Type: Research Article

Article Citation: Prof. Dr. Titik Triwulan Tutik. (2021). FAJAR NUSANTARA MOVEMENT (GAFATAR) HERESY IN THE PERSPECTIVE OF INDONESIAN ULEMA COUNCIL (MUI). International Journal of Research GRANTHAALAYAH, 9(2), 157-171. https://doi.org/10.29121/granthaa layah.v9.i2.2021.3382

Received Date: 31 January 2021

Accepted Date: 27 February 2021

Keywords:

Heretic Movement

Fajar Nusantara Movement

Criteria of Misleading

\section{ABSTRACT}

The existence of GAFATAR as ideology in Indonesia is not new group in the social and spiritual life. This ideology occurred in all the religions of the world, even its existence has happened thousands of years ago from the time of the companions of the Prophet Muhammad.

GAFATAR originally introduced himself as a social organization is essentially a continuation of al-Qiyadah al-Islamiyah founded by Ahmad Mushadeq who once claimed to be a prophet and apostle. Despite claiming to be based on Islam and Pancasila as the basis of the organization, GAFATAR actually developed the doctrine that deviate from Islamic shariah.

This paper is aimed to examine, first, the actual existence of the organization as the organization stated GAFATAR misguided and misleading. Second, the parameters that GAFATAR is a misguided and misleading organization.

The results show, that the First, the existence GAFATAR is basically misleading organization in the practical worship that is different with generally Muslim's worship. Second, GAFATAR categorized as a heretic movement because it has met the criteria of heresy that wasformulated by MUI.

\section{INTRODUCTION}

\subsection{PRELIMINARY}

The emergence of splinter group in Indonesia lately is like an iceberg phenomenon in the social and spiritual life. Starting from al-Qiyadah al-Islamiyah, Millah Abraham, the Holy Quran, Living life behind, Inkar Sunnah, Islamic reformer, Islam Jamaah Al-Zaitun, Jamaah Apostolate and others. An understanding of this, is occurred in all the religions of the world, even in the world of spiritual life grows various thought about the meaning of life through a variety of supernatural media. This kind of phenomena had already occurred thousands of years ago with various variants, ever since the time of the Companions of the Prophet Muhammad.

Many movements that grow and develop in Indonesia, basically divided into two groups: the movement that is allowed and misguided-misleading one. In 2007, Indonesian Ulema Council (MUI) has issued a decree of 10 misleading movement criteria, namely:

- Rejects one of the pillars of faith and the pillars of Islam.

- Believe and follow the aqidah that is not accordance with the Qur'an and Sunnah.

- Convinced of the revelation after the Koran.

(C) 2021 The Author(s). This is an open access article distributed under the terms of the Creative Commons Attribution License, which permits unrestricted use, distribution, and reproduction in any medium, provided the original author and source are credited. 
Fajar Nusantara Movement (Gafatar) Heresy in The Perspective of Indonesian Ulema Council (Mui)

- Rejects the authenticity or truth of the Qur'an.

- Doing interpretation of the Koran that are not based on the rules of interpretation.

- Rejects the Hadith as a source of Islamic teachings.

- Abusive, harassing or demeaning the prophets and apostles.

- Denying the Prophet Muhammad as the last prophet and messenger.

- Alter, add to or reduce the points of worship that have been set by the sharia, such as Haj is not to the Baitullah, not obligatory prayers five times.

- Infidel fellow Muslims without the proposition of syar'I, such as infidel Muslims simply because it was not his group.

Based on these criteria, the MUI has issued several fatwas related to any movement that is considered misguide and mislead that is growing in Indonesia. Even the Nahdlatul Ulama (NU) notes, since 2001 to 2007, at least about 250 deviant religious sects flourish in Indonesia. Of these, 50 of whom flourished in West Java. Here is a partial flow according to the MUI fatwa misguided and misleading.

Table 1: Data Cult \& Misleading According to the Indonesian Ulema Council (MUI) No Name MUI Fatwa Flow Flow Presence / Basic Law That Prohibits

\begin{tabular}{|c|c|c|c|}
\hline No & Movement name & Presence & MUI fatwa that prohibits \\
\hline 1 & Shia & $\begin{array}{l}\text { been around since the caliphate of friends / after the } \\
\text { killing of al-Husayn son of 'Ali bin Abi Talib, and } \\
\text { propagated by Abdullah bin Saba }\end{array}$ & $\begin{array}{c}\text { Defined as a stream of deviant } \\
\text { by the Fatwa Commission of } \\
\text { the Indonesian Ulema Council } \\
\text { on March 7, 1984 M / } 4 \\
\text { Jumadil End } 1404 \mathrm{H}\end{array}$ \\
\hline 2 & Ahmadiyah & $\begin{array}{l}\text { Active since } 1889 \text { in Pakistan, and into Indonesia in } \\
\text { 1924, founded by Mirza Ghulam Ahmad (1835-1906), } \\
\text { which is believed to also as their prophets / apostles }\end{array}$ & $\begin{array}{c}\text { MUI Fatwa No. } 05 \text { / kep / } \\
\text { munas II / MUI / } 1980 \text { stating } \\
\text { the heretical teachings; } \\
\text { MUI Fatwa } 2005 \\
\text { Rabithah nature silami (league } \\
\text { Islamic world) in Mecca } \\
\text { declared infidels flow outside } \\
\text { of Islam; }\end{array}$ \\
\hline 3 & $\begin{array}{l}\text { Indonesian } \\
\text { Islamic } \\
\text { Propagation } \\
\text { Institute (LDII) }\end{array}$ & $\begin{array}{c}\text { Active since } 1970 \text { in Ds. Bangi, Purwosari Kediri, East } \\
\text { Java, founded by Madigol Nurhasan Lubis bin Abdul } \\
\text { bin Tahir in Ershad (1915-1982) }\end{array}$ & $\begin{array}{c}\text { MUI Fatwa dated August 13, } \\
1994 \text { when he was named } \\
\text { Islam Jamaah; } \\
\text { MUI Fatwa 2005 } \\
\text { SK Attorney General No. } \\
\text { Kep.089 / D.a / 10/1971 dated } \\
\text { October 29, 1971 on the } \\
\text { prohibition LDII which at that } \\
\text { time was still called Islam } \\
\text { Jamaah }\end{array}$ \\
\hline 4 & $\begin{array}{l}\text { Religion } \\
\text { Salamullah / Lia } \\
\text { Eden }\end{array}$ & $\begin{array}{c}\text { Active since } 1995 \text { in Jakarta, founded by Lia } \\
\text { Aminuddin who claims to have met Gabriel and } \\
\text { allegiance to himself as the Mother Mari and renamed } \\
\text { Lia Eden }\end{array}$ & $\begin{array}{l}\text { MUI Fatwa No. Kep-768 / MUI } \\
\text { / XII / } 1997 \text { dated December } \\
\text { 22, } 1997 \text { fatwa heretical } \\
\text { teachings of Lia Aminudin }\end{array}$ \\
\hline 5 & Ingkar Sunna & $\begin{array}{c}\text { Appeared in the 1980s with its leader Mohammad } \\
\text { Irham Sutarto }\end{array}$ & $\begin{array}{c}\text { Expressed as deviant and } \\
\text { misled by MUI 1983; } \\
\text { Officially banned by decree } \\
\text { Attorney General No. Kep-169 } \\
\text { / J.A / } 1983 \text { dated } 30 \\
\text { September } 1983\end{array}$ \\
\hline
\end{tabular}




\begin{tabular}{|c|c|c|c|}
\hline 6 & $\begin{array}{c}\text { Negara Islam } \\
\text { Indonesia (NII) } \\
\text { KW-9 / Az-Zaitun } \\
\text { NII }\end{array}$ & $\begin{array}{l}\text { NII active since August 7, } 1949 \text { in Tasikmalaya, West } \\
\text { Java, which was first established by Sekarmadji } \\
\text { Maridjan Kartosoewiryo, which was later renamed } \\
\text { NII KW } 9 \text { (commandment Region-IX) led by Shaykh } \\
\text { Abu Toto Panjigumilang, } 1992 \text { in the village of Gantar } \\
\text { Indramayu West Java }\end{array}$ & $\begin{array}{l}\text { Expressed as deviant and } \\
\text { misled by MUI } 2003\end{array}$ \\
\hline 7 & Isa Bugis & $\begin{array}{c}\text { Active since } 1980 \text { in Jakarta, was first founded by Isa } \\
\text { Bugis (1926) in Aceh Pidie } 1926\end{array}$ & $\begin{array}{l}\text { Expressed as deviant and } \\
\text { misled by the Ministry of } \\
\text { Religious Affairs in } 1972 \\
\end{array}$ \\
\hline 8 & $\begin{array}{c}\text { Liberal Islam } \\
\text { Network (JIL) }\end{array}$ & This flow is active since 2001 , led by Ulil & $\begin{array}{l}\text { Expressed as deviant and } \\
\text { misled by MUI Fatwa } 2007\end{array}$ \\
\hline 9 & $\begin{array}{l}\text { Al-Qiyadah Al- } \\
\text { Islamiyah }\end{array}$ & $\begin{array}{c}\text { flow is centered in Kampung Gunung Bunder } \\
\text { Gunungsari Cibungbulan Bogor stood on July 23, } \\
2006 \text { by Ahmad Mushadeq alias Abdul Salam, who is } \\
\text { also their self-proclaimed apostle }\end{array}$ & $\begin{array}{l}\text { declared as deviant and misled } \\
\text { by MUI Fatwa No. } 04 \text { Year } \\
2007 \text { on October 3, } 2007\end{array}$ \\
\hline 10 & $\begin{array}{l}\text { Community } \\
\text { Millah Abraham } \\
\text { (Komar) }\end{array}$ & $\begin{array}{c}\text { Flow Komar is a change in the name of Al-Qiyadah Al- } \\
\text { Islamiyah, standing on } 12 \text { September } 2009 \text { centered } \\
\text { on Jalan Raya Puncak KM } 79 \text { Cisarua Bogor }\end{array}$ & $\begin{array}{l}\text { Bogor Expressed as deviant } \\
\text { and misled by MUI Fatwa in } \\
2010 \text {; } \\
\text { Banned by Aceh Governor } \\
\text { Decree No. } 9 \text { In } 2011\end{array}$ \\
\hline
\end{tabular}

Compiled from various sources

Fajar Nusantara Movement (GAFATAR) nowadays has become phenomena. GAFATAR since its presence has aroused strong suspicion as a deviant organization. Starting from the public reports that some members of his family were found missing, were later discovered to be members of GAFATAR and moved to Mempawah in West Kalimantan.

GAFATAR originally declared itself a social organization, which performs a variety of social activities such as social charity, blood donors, and other social activities. This assertion was delivered Mahful M. Tumanurung as Chairman GAFATAR through opening speech GAFATAR III National Meeting on Thursday 26th February 2012 at Balai Sudirman Jakarta, which confirms that GAFATAR will not evolve into secret societies Religious Organization and Politics. GAFATAR only do every whim and and full compliance with the plan and sooth solely to obtain mercy, favor and grace of Allah SWT.

Despite claiming to be based on Islam and Pancasila as the basis of the organization, GAFATAR actually developed the doctrine that deviate from Islamic shariah. Including the most important law, the five-daily praying. They consider the one praying as idolaters, they aspire to fight against people who pray, they were a different creed, no longer "ASYHADU anna Muhammad Rasulullah" but "anna ASYHADU Al-Masih Al-Maw'ud Prophet".

According to M. Amin Jamaluddin, GAFATAR is misguided and misleading organization that is the embodiment of al-Qiyadah al-Islamiyah, so many beliefs that deviate from the principles of pure Islamic teachings. In addition to having a new creed, in which each of his followers asked faith in al-Masih al-Promised Messiah and regard those who do not believe in him are infidels, GAFATAR as al-Qiyadah al-Islamiyah also do not require the five daily prayers, fasting, paying zakat, and pilgrimage.

The existence of GAFATAR itself as a social organization is based with easy to maneuver and escape the careful monitoring of the various parties. The new organization was blowing up into a public discussion after the MUI issued a fatwa misguided Number 06 Year 2016 on February 3, 2016. The fatwa is based on the results of the assessment of the Commission for the Assessment and Research on Flow Organization MUI Fajar Nusantara (GAFATAR) on 28 and January 30, 2016, which states in part:

- GAFATAR is a metamorphosis of Al-Qiyadah Al-Islamiyah and Community Millah Abraham.

- GAFATAR same religious affinity with the religious ideology of Al-Qiyadah Al-Islamiyah and Community Millah Abraham;

GAFATAR spreading religious belief and understanding of: (i) the carrier treatise of God Almighty, as the messiah and savior, namely Ahmad Musadeq alias Abdus Salam Messi is essentially end-time prophet after the 
Fajar Nusantara Movement (Gafatar) Heresy in The Perspective of Indonesian Ulema Council (Mui)

Prophet Muhammad; (Ii) the obligation, the five daily prayers, fasting Ramadan, and pilgrimage; (Iii) confound (syncretism) between the teachings of Islam, Jews and Christians to interpret the verses of the Koran are not in accordance with the rules of interpretation.

Based on the explanation of the Attorney General on the forum tabayun (clarification) in meeting the MUI Fatwa Commission and the Commission for Commission for Assessment and Research MUI on February 2, 2016, which basically stated that GAFATAR originally engaged in the social sphere, but in the development of teaching religious beliefs, which is metamorphosis of the flow of Al-Qiyadah Al-Islamiya and the flow Millah Abraham.

Referring to these results, the MUI through the MUI Fatwa Number 06 Year 2016 concerning the organization flow Fajar Nusantara (GAFATAR) on February 3, 2016, provides:

First, the GAFATAR (Gerakan Fajar Nusantara) is a religious sect that puts Ahmad Moshaddeq as a spiritual teacher as to believe and teach the doctrine, among others; (I) the carrier treatise of God Almighty, as the messiah and savior, namely Ahmad Moshaddeq alias Abdus Salam Messi is essentially a prophet after the Prophet Muhammad; (Ii) do not require the five daily prayers, fasting Ramadan, and pilgrimage.

Second, the GAFATAR is misguided and misleading, because: a metamorphosis of the flow of al-Qiyadah alIslamiyah already said misguided through the MUI Fatwa Number 04 Year 2007 and teaches understanding and confidence Millah Abraham, that is lost is misleading because it confuses the teachings of Islam, Christianity, and Jews to interpret the verses of the Koran that do not correspond with the tafsir.

Third, scholars, government and society have to join together in coaching, guidance, and supervision of administrators, followers and sympathizers of the former GAFATAR to return to the correct Aqeedah.

Besides the MUI Fatwa No. 6 of 2016 regarding the flow GAFATAR misleading, Kesbangpol Ministry of Interior on 5 April and 30 November 2015 never made a letter to Kesbangpol provincial and district / city for not issuing Registration Certificate to the Community Organisations GAFATAR and in order to conduct surveillance and monitoring activities of these organizations. Based on the letter, in fact the Interior Ministry had anticipated the danger of GAFATAR mass. Even earlier through a letter Kesbangpol Ministry of Interior No. 220/3657 / D / III / 2012 dated 20 November 2012, the Ministry of Home Affairs has banned organizations of GAFATAR, but the organization was renamed the State gift of the Lord of Hosts.

Based on the fact that the existence of flow GAFATAR be something interesting very urgent to do research, for several reasons: First, GAFATAR has declared itself as a community-based organization but in fact engaged in activities contrary to the faith. Second, the GAFATAR actually comprise the "new clothes" of the flow of al-Qiyadah al-Islamiyah, which later changed its name become Community Millah Abraham is both a prohibited organization and declared heretical-warped by the MUI, but in fact this flow is still growing and experiencing anomaly. For that reason, the study of the flow is very urgent GAFATAR do.

The issue as a question of the study includes the following: First, how does the existence of the organization as the organization stated GAFATAR misguided and misleading. Second, what are the parameters that GAFATAR organization is an organization that is misguided and misleading.

\section{ORGANIZATION OF ORGANIZATION DAWN ARCHIPELAGO (GAFATAR)}

\subsection{ESTABLISHED HISTORY GAFATAR}

Minister of the Interior, Tjahjo Kumolo, explaining the history of the formation of CBOs GAFATAR starting from the split between Ahmad Mussadek and Panji Gumilang, both of which are members of the Islamic State of Indonesia (NII). After the split the joint venture, Panji Gumilang established a new organization called the Islamic State of Malaya (NIM). While Ahmad Al-Qiyadah Mussadeq establish al-Islamiyah, which was later renamed Community Milah Abraham (Komar). Komar did not last long, especially after the Indonesian Ulema Council (MUI) issued a fatwa that these organizations go astray. Reinforced by four years of criminal decisions against his boss Ahmad Mussadeq in 2009. Furthermore, to eliminate the traces, the organization was renamed the CBOs GAFATAR led Mahful Muis M. Tomanurung to "impersonate" social activities.

GAFATAR recruitment pattern is dependent on the target who wants to be recruited, including approaches from social services that could attract public sympathy. For students, GAFATAR recruit through halaqah, closed meeting, or a small prayer. Students were recruited in general is that they still lay religious knowledge so that when introduced to a particular school of thought and organization does not reject and receptive. For professional 


\section{Prof. Dr. Titik Triwulan Tutik}

workers, GAFATAR tend to take advantage of the limited level of religious understanding. No wonder if GAFATAR followed by those who rated established intellectually and financially. In addition, recruitment is done by GAFATAR also not closed to those who are economically weak by the lure will be given jobs at high wages.

Yudhistira, former Chairman GAFATAR Yogyakarta, provide information related to the acquisition of funds GAFATAR organization that funds from outside parties, but all of the funds obtained from the organization's activities comes from the dues of its members and residents of the village where they are carried out.

On 2 November 2011 CBOs GAFATAR proposed a registration to the Ministry of Internal Affairs to be passed into organizations, but was rejected. And so, on up to three times the asking but still rejected by Kesbangpol. Then, on April 5 and November 30, 2012, the Director General Kesbangpol Kesbangpol sending a letter to the provincial and district / city for not issuing Registration Certificate to CBOs GAFATAR and for supervising and monitoring the activities of these organizations. By doing so, in fact the Ministry of Home Affairs has anticipated the danger of this GAFATAR community organizations. However, if there are areas that Kesbangpol issuing permits for CSOs GAFATAR before 2012 it is considered reasonable, because at that time there has been no circulars Director General Kesbangpol Kemendagri.

GAFATAR is an organization that claims engaged in social and cultural fields. This organization has a website in gafatar.org site. Site registered since 2011 are still valid until October 2016 . The vision, mission, objectives and work program of the social organization is absolutely no mention of the name of one religion.

In GAFATAR written rationale that Indonesia called yet fully independent of the colonial system of neocolonialist and neoimperialis. "This fact makes us be triggered to do. I cannot sit still without doing anything for the progress and glory of the nation." Some activities such as blood donation GAFATAR to trail commemorating Memorial Day 2012. However, GAFATAR still get rejection residents because it is considered heretical religious sect.

Observers terrorists, Al Chaidar said GAFATAR is the result of the metamorphosis Milah Abraham led by Ahmad Mussadeq, then expand again into NII or better known as KW9 up GAFATAR formed. Linkage with NII is what causes the permission of the Interior Ministry Kesbangpol not go out. GAFATAR never registered through letter No. 01 / Setjend / dpp / x / 2011 dated November 2, 2011. Based on the advice of various ministries and agencies, including BIN, there is a recommendation to reject GAFATAR serve as an officially registered organization. Therefore, until now GAFATAR is an illegal organization.

Former followers of the Islamic State of Indonesia (NII), Ken Setiawan said the basic of GAFATAR is not much different from the NII. First, GAFATAR instill sympathetic to the citizens through a variety of positive activities such as blood donation, training or free tutoring. Second, conduct propaganda in the form of injustice is acceptable citizen, became a powerful formula to recruit members, especially the younger generation.

The existence of a new GAFATAR become big issues when it is indicated that many community members who have lost a family member is known to be moved Mentawah to West Kalimantan. GAFATAR today have built community and agricultural areas as well as various other ancillary facilities designated for relocated communities of Java and / or other islands. They did struggle on the territory of the island of Borneo. The area is by GAFATAR planned as propaganda Development Center as well as the Capital City (Umm Al-Qura). GAFATAR organizations in West Kalimantan to declare themselves and renamed the State gift of the Lord of Hosts.

\subsection{PRINCIPAL DOCTRINE GAFATAR}

GAFATAR as the flow makes Mushadeq Ahmad as "Prophet", then the flow is equal points with the teachings of Al-Qiyadah Al-Islamiyah and / or the Community Millah Abraham (Komar), among others:

That adopted them is Millah Abraham, for Abraham is the father of the Prophet.

Among GAFATAR there is no teacher, but it is enough to learn his own book Taurot, Gospel and Quran, by way of an interpretation of its own.

Prayer there are two types, namely prayer ritual or prayer Payer, carried out once a day with a count rokaan odd (11 rokaat), during the third night that the end (clock 01:00-4:00 pm.) To pray and application execution by doing good neighbor and do not lie.

Terms entered into GAFATAR not by reading the Creed, but with required reading surah Al-Mumtahanah Clause 12, and perform allegiance (oath) which reads:

1) In the Name of Allah, Most Compassionate and Merciful, I promise:

2) I declare promise to God witnessed by the transmitter of gods responsible. 
Fajar Nusantara Movement (Gafatar) Heresy in The Perspective of Indonesian Ulema Council (Mui)

3) I say this consciously and earnestly sincere, no coercion from anyone

4) I declare faith in Allah and His messenger, and renounce all forms of devotion to other than Allah, and able to serve as a treatise Allah to invite the people to uphold the path of righteousness on God's earth.

5) I will not steal, commit adultery, murder, lying and will not do ungodly against the teachings of Allah

6) I am ready to accept the guidance of God's command transmitter into my Trustees;

7) Allah would justify a promise I stated this and encourage me to be a people blessed

8) Praise be to Allah, the Lord of hosts, the God of Abraham.

9) Praying five times a day, alms and fasting Romadlon not compulsory, since Islam is now still in the dark / still not perfect

10) Millah teachings intention is to reunite To Judaism, Christianity, and Islam, in order to correct doctrine.

11) Millah principal teaching derived from the Qur'an, and did not acknowledge the position of the hadith as a source of Islamic teachings. All the problems, if not in the Qur'an, does not need to be implemented.

12) One of the activities undertaken, to enter into these teachings are embedding Purest Spirit.

In essence the teachings apply to followers GAFATAR includes two things: the teachings related beliefs and teachings related to worship.

Doctrine GAFATAR relevant to Aqidah

1) The new shahada Lafadz their new creed is "ASYHADU an laa ilaha ill Allah wa ann ASYHADU Still alPromised Prophet".

2) If the followers of GAFATAR committed a sin, then they only need to redeem their sins to Al-Masih AlPromised to give some money to him.

3) This stream has the understanding, that the teachings brought Moses, Jesus and Musaddeq are the same, because it has same source of teaching, namely God.

4) The teachings of this flow are based not only the interpretation of the teachings of Islam, but also taught Christian ideologies, even many quotes and bases its teachings on the Bible.

5) Broadly speaking, the verses mutashabihat (according to al-Qiyadah version) is that talking about doomsday. Hell is regarded as a symbol of the destruction of the power of ignorance the Quraish in the time of the Prophet because of the success of the apostle and his companions. For example, in the Tafsir al-Haqqah: 1621, the interpretation of paragraph 6 of the QS. Al-Ma'arij, interpretation of QS. Al-Muzammil.

6) Grouping people into three groups, namely: Ashabul Araf is Assabiqunal Awwalun, Yamin is a group of Ansar Companions, Companions Syimal is opposition against the apostle.

7) The interpretation of the angel who carry Throne as it is written in verse. Al-Haqqah paragraph 17 , alQiyadah interpret it as the ro'in angel or mas'ul that have been arranged in seven tiers structure and the strength of the mass of the earth.

8) Interpretation (Man fis samma: ie who is in the heavens), in a letter QS. Al-Mulk verse 16 is defined as celestial bodies and in paragraph 17 were interpreted as the ruler of the sky.

9) Noah's Ark is interpreted as a means of propaganda organization controlled by Noah as shipman. Noah's family are the believers who follow him, while the animals entered in pairs is the passenger's peop le who come to follow him. Oceans in question is Noah idolatrous nation.

10) Al-Qiyadah interpret nature jin, a kind of man whose life sealed off from ordinary human relationships (people who have the ability to think and tech that has always been a leader in human society) categories as defined in QS. Al-Jin is a pious Christian people who came from the Arab north.

The GAFATAR Doctrine Pertaining to Worship

1) GAFATAR group has a way of worship which is mandatory, known by 6 programs of worship, namely:

Qiyamul Lail (night prayer / tahajud)

Hafiz Quran (Quran memorizing)

Taklim (Learning)

Talwiyah (Delivering the da'wah)

Taswiyatus Shufuf (close up shof)

2) shodaqoh

Shodaqoh is the corrective action of programs by issuing Amwal (assets) as proof of his love for God. Not implementing the five obligatory prayers, charity, fasting, Hajj and so on. This is because Al-Qiyadah Al-Islamiyah 


\section{Prof. Dr. Titik Triwulan Tutik}

found now they are still in the phase of Mecca, so they only focus on teaching their beliefs, and does not perform its obligations as required five times a day, alms, fasting, pilgrimage and so on.

\subsection{OBJECTIVES OF GAFATAR}

See the activities done by GAFATAR, this organization has at least the intent and purpose of forming a new religion and establish an Islamic state.

\section{Forming a New Religion}

GAFATAR according to the narrative chairman of Islamic Research and Studies Institute (LPPI), M. Amin Abubakar, is a community organization that has points of doctrine in the form of a very controversial proposition of replacing the shahada, is not obliged to prayer and fasting, to recognize Ahmad Moshaddeq as prophet after the Prophet Muhammad as Al-Masih Al-Maw'ud.

Attorney General's Office as the competent institutions have been officially declared Fajar Nusantara movement (GAFATAR) as a banned terrorist organization, for teaching and running a deviant religious teaching that indicated under the guise of social activities. Furthermore, according to the Chairman of the Islamic Research and Studies Institute (LPPI), M. Amin Abubakar, the organization not only deviate GAFATAR but further more ambitious to spread the new religion in Indonesia, namely the unification of Islam, Jews, and Christians.

The indicators were noted in some book covers into the handle GAFATAR group. First, the symbol of Islam, Judaism and Christianity are very clearly posted in the book "Al-Masih Al-Maw'ud \& Purest Spirit" written by Ahmad Moshaddeq.

Second, subtitled in one handbook GAFATAR there are words that suggested the establishment of a new religion, for example, the handbook written by the chairman Gafatar, "Mahful M. Hawary" with the subtitle "Building Unity of the Jewish faith, Christianity, and Islam". Its content is an interpretation of the Torah, the Gospel, and the Qur'an.

Third, in a book entitled "Understanding and Responding to the tradition of the Lord: Rise of the hated but missed" by Ahmad Mesiyyakh, mapped: (1) that according to the calendar BC that since the birth of the people headed by Muhammad in the year $624 \mathrm{BC}$, plus 700 years heyday until traditions destruction $(1,324 \mathrm{M})$, plus the extra time tradition of 700 years, then according to the analysis of the tradition of God's chosen people will be resurrected at the beginning of the 21th century BC (yr. 2024 BC). That is, at the beginning of the century, God's building will stand back. (2) Mesiyyakh in the same book on page 180 mentions, this century has entered the 21st century, which means it is time for God to work reviving the concept of the sky through the life of the people he loves. (3) Messyiakh asserted in the 21st century there is a young man who will be the chosen ones and the people supervising the tradition tp complete God as a logical consequence of a revival. The human child has a spirit-insightintegrity such as Moses, Jesus, and Muhammad.

Fourth, in the book Liabilities Respect Day "Seventh" (Sabbath) issued by the Community Millah Abraham (Komar). In this book is described: (1) the holy day for Gafatar adherents is Saturday. Komar concluded that after interpreting letter and verse in the Torah, the Gospel, and the Qur'an in his book. (2) on the case. 13 For example, the Torah and the Qur'an together to explain the process of creation of events taking place step by step, in a rational way in six stages and the seventh stage of the entire universe reaches its perfection. The creator, God of the universe and then rested from all his work which he had done it. (3) on the next page, the Gospel is also expressed in Genesis [2: 3], God blessed the seventh day and made it holy, because on it he rested from all his work which he had done it. (4) Then on p.15 Komar interpret, Understanding God's rest does not mean he stopped taking care of his creatures. But, I mean, quit creating at a better level again. It was not necessary for him to do on the seventh day all His creation it has been perfect.

\section{FORMED THE ISLAMIC STATE}

From the research compiled by Amin Abubakar, there are six stages planned since the establishment of alQiyadah Al-Islamiyah, which is a step towards the establishment of the Islamic State is now carried by GAFATAR. The first stage is Sirrun, the secret organization, preaching secret and secretly recruiting members who, according Ami has been done since the coronation Moshaddeq in 2006 with the formation of Al-Qiyadah Al-Islamiyah until recently a GAFATAR. 
Fajar Nusantara Movement (Gafatar) Heresy in The Perspective of Indonesian Ulema Council (Mui)

The second stage, Jahrun, that preach openly, assesses openly, recruiting members openly. This is done if they calculated the strength has been qualified against the forces of infidels, said Amin, who claimed to have been steeped in false teachings in Indonesia since 1968.

The third stage, Hijrah, ie the representation of the history of migration from Mecca to Medina to the founding capital of the State which they called Umm Al-Qura. This is being done according to Amin GAFATAR members, but when seen with the eyes of a layman looks just the issue of the disappearance of family members only. The third stage shows that actually GAFATAR members have committed to finally decided to move. It is also interesting; people will report the loss of their family members many who claim to go to Kalimantan with reasons to follow their husbands to work openly want to take care of GAFATAR.

The fourth stage, Qital, namely open war with the infidels for the triumph of their version of Islam. The fifth stage, Futuh, which won on the battle against the infidels. They are very confident with the fifth stage, this Futuh. They are very confident will win the war. The sixth stage, the Caliphate, which formed a government of their version of an Islamic state to enforce their version of Islamic law.

\section{GAFATAR SECT'S MISGUIDED PERSPECTIVE}

\subsection{MISGUIDED CRITERIA}

The sect is meant ideology, opinion, or believed that followed, while misguided means very wrong. Cult means ideology, belief or opinion be a person or a group of extremely misguided. Meanwhile, according to Farid Effendi Zainal, a cult is a flow that deviates from the path of truth shown by religion, the path is al-Qur'an and al-Hadith, and the path of the majority of Muslims (ijma ').

According Yulkarnain Harahab and Supriyadi, to assess an organization categorized misguided or not in the view of Islam should look at the provisions contained in the Qur'an and Sunnah, which is methodologically a heretical teaching say if it deviates from the basic teachings sourced from Qur'an and Sunnah.

Borrowing the term Kuntowijoyo, adherents of a cult is a splinter group that were able to organize themselves well. Even morale (ghirah) to continuously disseminate their ideology to the public can be fairly high. As a result, those present were able to have thousands of followers spread across several regions.

If referred to the way the recruitment of members is also quite simple. Typically, the splinter group of individuals tends to use methods of proselytizing (da'wa fardliyah). They came to house's objects of propaganda. Book discussions, study groups with a relatively small number of pilgrims are an effective means of hook members which are generally young people in their teens. It is common knowledge if the young people are always liked by all sorts of new things. Based on the understanding of religion that are less mature, young people will be very easy to be swayed by the offer of the teachings of strange and unfounded.

If we recall the expression Kuntowijoyo, it will be clear that the existence of the splinter group would be klilip (read: interference) among mainstream Islam. This is because the contents and teachings of material not in accordance with the provisions set out in the source of Islamic teachings, referring to Al-Qur'an and Sunnah that are authentic.

However, the problem may be related to freedom are rampant in our country, especially in the religious life that occurred during the reform era has spawned a lot of opportunities and challenges. Various missionary activity went smoothly and a variety of fundamental Islamic values freely voiced no major obstacles. But on the other hand, with the freedom that also movements or groups that raise thoughts, understanding and activity incompatible with the aqidah and syariah Islam also freely move and develop in society.

Komaruddin Hidayat, a cult that developed in the country need to be handled carefully, comprehensively to avoid excessive emotional sense. Like a nail that is attached on top of a timber, the more it will anchor a strong hit. While Amidhan said, the emergence of a cult phenomenon was caused by too much the number of poor and unemployed people in Indonesia. As a result, many young people who do not have the funds, after graduating high school, they cannot go to college. While scholars were already difficult to find a job. Finally, they are unemployed.

According to Abdul Madjid, there are several indicators to assess a religious sect deemed heretical. First, deny the greatest Allah SWT. Second, became one of the deniers of Allah's Apostle. Third, deny the Sunnah Rasul / dissenter as-Sunnah. Fourth, deny the Prophet Muhammad as the last prophet, or in other words claiming to believe 


\section{Prof. Dr. Titik Triwulan Tutik}

their prophet or a prophet after the Prophet Muhammad. Fifth, have aqidah against the al-Quran and al-Hadith has been agreed upon by scholars (ijma 'ulama).

Indonesian Ulema Council (MUI) on Rakernas 2007 set of ten criteria of a stream can be classed lost. According to Ichwan Sam, some of the factors are behind the current guidelines. Among other things, First, freedom, especially in religious life, which occurred during the reform era has spawned a lot of opportunities and challenges. Various missionary activities went smoothly and a variety of fundamental Islamic values freely voiced no major obstacles. But on the other hand, with the freedom that also movements or groups that raise thoughts, understanding and activity incompatible with the faith and Islamic law also freely move and develop in society.

Second, thinking, understanding and activity incompatible with the faith and sharia should certainly not be grown just in the community because it would cause unrest besides people will cause casualties among people who had been misled. Therefore, there should be an earnest effort to deter and stop the flow of it and remind them to return to the right path.

Third, as the heir to the prophet scholars have a role and responsibility in guiding the people to remain committed and run values of true Islam as taught by the Prophet Muhammad. Therefore, scholars should be firm, wise and prudent for any irregularities, both associated with Islam and Islamic theology. Irresolution attitude will make the deviation in the faith and sharia increasingly prevalent and widespread.

Fourth, the MUI as container clerics and Muslim intellectuals must take an active role in maintaining the values of Islam and protect the people from any misunderstandings and deviant sects. Among others, establish guidelines to address a group or the sect heretical or not based on the analysis, studies and arguments which can be accounted for. This determination will be a guideline for Muslims in assessing an understanding, so that it can react properly.

The basis and nature of the determination of the flow criteria is not born of personal or group interests. However, the determination of straying a stream or groups based on Al-Quran, Al-Hadith, Ijma and Ijtihad and scholarly opinion venerated. Determination straying a stream or group is responsive, proactive and anticipatory. Such determination is done collectively by a joint meeting of the MUI consisting of the Leadership Council, the Commission for the Assessment and Fatwa Commission.

According to MUI, errors and misguidance is something different. Mistakes are mistakes pemahanan and practices regarding matters of sharia that consequently only maksiyat. Average apostasy are misconceptions associated with proceedings creed or sharia but believed to be true that the consequence is kufr.

Before the introduction of a stream or straying first research group to collect data, information, evidence and witnesses, if any, about the understanding, thinking and activity movements of the Commission assessment. First assessment was done on the opinion of the imam schools and the scholars / experts with regard to things that made thoughts and things into the group's activities or stream it by the Review Commission.

Then, do the calling to the leadership of flow or groups and expert witnesses to do tahqiq and tabayyun on a variety of data, information and evidence obtained about the thought and activity movements or groups of them at once taushiyah if indeed one that is concerned to leave the thinking and understanding and wrong activity and back to the right path. The results of these activities submitted to the Council Leader. If deemed necessary Fatwa Leadership Council asks the Commission to discuss and issue a fatwa.

The 10 criteria astray by MUI, namely: (1) To deny one of the pillars of faith are six (6) that believes in God and the angel of his, to the books of his, to Apostles Him, to the Hereafter, to Qadla and Qadar and the pillars of Islam are five (5) that is to say two sentence creeds, establish the prayer, issued alms, fasting during Ramadan, perform Haj. (2) To believe or follow the creed which does not correspond to the arguments syar'i (Al-Quran and As-sunnah); (3) Convinced after the revelation of the Quran. (4) To deny the authenticity or truth of the Koran; (5) the interpretation of the Koran that are not based on the rules of interpretation (6) To deny the position of Prophetic traditions as a source of Islamic teachings; (7) Insulting, harassing or demeaning the prophets and apostles; (8) To deny the Prophet Muhammad as the last Prophet and Messenger; (9) Change, add or reduce points of worship that have been set by the Shari'ah, such as Haj is not to the House, praying fardlu not 5 times. (10) judge as kufr person to the fellow Muslims without the proposition syar'i, such as the Muslim infidel simply because it was not his group. 
Fajar Nusantara Movement (Gafatar) Heresy in The Perspective of Indonesian Ulema Council (Mui)

\subsection{CULT GAFATAR ACCORDING TO THE INDONESIAN ULEMA COUNCIL}

GAFATAR originally introduced himself as a social organization is essentially a continuation of the flow of al-Qiyadah al-Islamiyah, which was founded by Ahmad Mushadeq who once claimed to be a prophet and messenger. This flow is very disturbing society.

According to M. Amin Jamaluddin, there are many irregularities that occurred in the teachings GAFATAR. First, the main visible deviation from the creed has been very different. In the teaching's creed reads ASYHADU GAFATAR an laailaha illallaah ASYHADU anna wa Al-Masiihal Maw'uuda Rasulullah (I bear witness that no god Besides Allah, and I testify Al-Masih Al-Maw'ud is the messenger of Allah).

Second, other irregularities seen in the book "Purest Spirit that Down to Al-Masih Al-Maw'ud", page 175 by the same publisher, when someone does a worship without following the Prophet after Muhammad, Al-Masih AlMaw'ud, then it will not be accepted worship.

Third, the deviation in the principal teachings summarized in several handbooks GAFATAR members, such as the five daily prayers are not obligatory because the time has now come back into the period of lawlessness Makkah and Islam (Al-Quran and Al-Hadith). According to the flow GAFATAR, the five daily prayers are not compulsory, but require Qiyamul Lail (night prayer) and prayer time also setting of the sun rising as practiced by the Prophet Muhammad during the period of Makkah. If the night prayer is not done, then they have to atone, in the form of money shodaqoh the amount determined by the prophet, namely Moshaddeq.

According to one of the principal teachings of GAFATAR, apparently not only penance that requires money shodaqah, if you want to speak specifically with Moshaddeq as a "prophet" should also issue shodaqah before the talks. Their penance is described in a handbook GAFATAR, namely Islam Hanif: Will Go to Heaven by Robert P. Walean things. 20.

Indonesian Ulema Council through Fatwa No. 6 of 2016 concerning flow organization Fajar Nusantara (GAFATAR), states that: First, the flow GAFATAR is misguided and misleading, because it is a metamorphosis of the flow of al-Qiyadah al-Islamiyah already said deviant and misled by the MUI. Second, the flow GAFATAR teach understanding and confidence Millah Abraham misguided misleading because it confuses the teachings of Islam, Christianity and Judaism to interpret the verses of the Koran are not in accordance with the rules of interpretation.

Here is an explanation related to the views expressed heretical teachings GAFATAR mislead by MUI.

- Their Prophet / Apostle after the Prophet Muhammad

- Flow GAFATAR believes that Ahmad Moshaddeq was an apostle who brings new treatise for them. This belief also indicated that they believed there was an apostle after the Prophet Muhammad.

- Gafatar is clearly misguided belief misleading, because Islam believes that there is no longer an apostle who brings new treatise after the Prophet Muhammad, because he was the final prophet of the previous prophets. This is confirmed in the Qur'an Surat al-Ahzab verse 40:

ماكان محمد أباً أحد من رجالكم ولكن رسول الله وخاتم النبيين

It means: "Muhammad is not the father of a man among you, but he is the Messenger of Allah and the cover of the prophets."

And to us are commanded by God to obey treatise which was revealed to Prophet Muhammad.

قل أطيعو ا الله و الرسول فإن تولو ا فإن الله لا بحب الكافرين

That is, "Say:" TObey Allah and His Messenger; if you turn away, then Allah does not love the disbelievers ". (Qur'an, religious high Imran [3]: 32)

In al-Qur'an Surat an-Nisa verse 115, Allah has promised to those who opposed the teachings of His Apostles.

"And those who oppose the Apostle after the obvious truth for him, and follow the path that is not the way people believers, we let him freely to the error has mastered it and we put it into Jahannam, and Jahannam is the worst place back."

Regarding the existence of the Prophet Muhammad as the last messenger, are also described in the hadith.

"From Abi Hurairah ra he said: Rasulullah SAW said: Formerly the Israelites led by prophets, each a prophet dies, it is replaced by another prophet. And indeed, there is no prophet after me ...." 
Prof. Dr. Titik Triwulan Tutik

In another hadith He also said, "Rasulullah SAW said: the true apostolic and prophetic has stalled. Therefore, there is no longer an apostle and prophet after me ...."

Under the terms of al-Qur'an and al-Hadith it is clear that the Prophet Muhammad, the last prophet and also the cover of the prophets. No apostle thereafter that brings new doctrine. Believes the apostles after Muhammad teaches new treatise is the real heresy and apostasy.

\subsection{RITUAL PRAYER GAFATAR}

GAFATAR core teachings, referring to understand Komar stating that prayer consists of two kinds, namely the ritual prayer and the prayer of applications. Ritual, literally means "techniques (means, methods) to create a custom to be holy (sanctify the custom)." The ritual also means creating and maintaining the myth, also social and religious customs. Rituals are also significant personal or group. Its form can be a prayer, dance, drama, words such as "amen" and so on. Ritual Prayer term is referring to the implementation of the prayers that use certain techniques and organization so that it becomes a sacred worship. Prayer in this sense is commonly known as worship mahdoh, namely worship ordinances and rules set by Allah and His Prophet, nature ritual transcendental, and more on building human relationship with Allah, hablun minalloh, carried out with the Shari'a already determined. The ritual is called because it covers the methods and procedures for certain, either shar, I and fiqhi, transcendental because it leads to communication with Yang at the Top, which Allah SWT.

Worship mahdoh there are two types, namely restricted (mahdoh muqoyadah) eg prayer, zakat, etc., and are not restricted (mahdoh ghoiru muqoyadah) tahmid eg, beads, Takbir, etc. In this context, if Komar uses the term prayer ritual, then indeed the provisions concerning this ritual is something muqoyyadah, according the proposition syar'i.

Terms of Use prayer application, refers to a method in understanding Islam from the side of epistimology, the method approach mulahadhah thabi'iyah (natural observation) this method can be used to assess a person's religious life through symptom observed behavior. Thus, prayer in this sense, is all action and behavior of our daily lives must reflect the values contained in the execution of daily prayers, and those prayers, should be farthest from any actions shameful and unjust, because the application execution prayer major is, he had removed us from the shameful and unjust deeds.

In the teachings of GAFATAR, establish prayer, carried out by doing good things, and abstain from all indecency and evil. Teachings GAFATAR about prayer that tends to violate the provisions of the Islamic Sharia, among others:

1) Prayer Five Times (in their language: Ritual Prayer) is not required because it is still in a period of darkness, that is not mandatory, in addition to the absence of a basic implementation of Prayer Five Times in the Qur'an. The boundaries of the time were not mentioned in the Qur'an.

2) Prayer ritual that is required is one in a single day and night, held at the end of the third night, as in Surah Al-Muzammil: paragraphs 1 to 4, which means:

3) "1. 0 you wrapped (Muhammad), 2. get up (for prayer) at night, except a little (thereof), 4 or more; And read the Quran slowly. (QS. Al-Muzammil verses 1-4)"

4) If you've been praying applications, ie practicing the teachings of prayer in daily life, keep away from indecency and evil, then, the prayer ritual does not need to be implemented.

Whereas in Islam, a lot of propositions ordered the conduct of praying five times, whether sourced from the Quran and al-Hadith. According to experts, in the Qur'an found 30 orders establish the prayer, 27 pieces of them together with the order to pay zakat. This means that those who pray, they are also obliged to pay zakat if qualified.

Establish the prayer means praying in accordance with the guiding. From how doing wudlu, tayamum, shower, intending to prayer, Takbir, until greetings, time discipline, and continuous prayer. Salah can only be done at the times set by Allah SWT. When the prayer is being outside the present time, then the prayer is not valid. Unless there is a particular barrier udzur or sharia is unacceptable. As doing the prayer with Jama' (become one time) the other prayer times. Or praying for those who forgot or fell asleep, then when the conscious and knowing that there were prayers were spared, he shall do it though it was out of time. No matter when prayers are outside of time deliberately and beyond the provisions of the law is justified, then the prayer becomes invalid.

In the event must perform prayers on time, Allah has said in the Qur'an:

إن الصلاة كانت على المؤمنين كتابا موقوتا 
Fajar Nusantara Movement (Gafatar) Heresy in The Perspective of Indonesian Ulema Council (Mui)

This means:

"... Indeed, the prayer is fardhu that timed over those who believe." (QS. An-Nisa: 103)

In a letter Hud verse 114, also described: "And establish regular prayers at the two edges of the day and at night beginning Courant. Indeed, the good deeds were abolished bad deeds. That is a warning for those who remember "(QS. Hud: 114).

According to mufassriin, mentioned in this verse prayer time, ie during the second edge, ie the morning prayer and Asr. And at the beginning of the night Courant, is namely Maghirb and Isya`.

Specifically, on the argument about prayer times, we may refer to Rasululah SAW hadiths that are authentic and qath `i. Not less qath $i$ with the arguments of Al-Quran Al-Kariem. Among these hadiths are the following:

From Jabir bin Abdullah ra. that the Prophet was visited by Gabriel and told him, "Get up and do the prayer." So, he prayed noon, when the sun slips. Then when Asr ahead and Gabriel said, "Wake up and do the prayer." So, he SAW perform Asr prayer when the length of the shadow of all things equal to the length of it. Then the Maghrib time ahead and Gabriel said, "Wake up and do the prayer." So, he SAW prayed Maghrib when the sun sets. Then when Isya` ahead and Gabriel said, "Wake up and do the prayer." So, he prayed Isya` SAW when syafaq (mega red) disappears. Then the Fajr time ahead and Gabriel said, "Wake up and do the prayer." So, he SAW praying Fajr when dawn broke / eve. (HR. Ahmad, Nasai and Tirmizy)

In the Authar Nailul mentioned that Al-Bukhari said that this hadith is the most authentic hadith about prayer times.

\section{Implementation of the prayer ritual GAFATAR}

In the basic teachings of GAFATAR states that the obligation to pray only once a day and night, held at the end of the third night, as in Surah Al-Muzammil: paragraphs 1 to 4.

Shaikh Jalaluddin Assuyuthi in the book: FII Lubabunnuqul asbaabunnuzul, explained that the evening prayer as in Surah Al-Muzammil verses 1-4 is a proposition regarding the implementation of the evening prayer that was originally required, but after going down in the 20th paragraph of this letter, its legal circumcision.

If GAFATAR group holds that in a day and night, praying that must be as in Surah Al-Muzammil verses 1-4, then it is a false assumption, because the verse is not related to prayer five times, but talking about the night prayer which initially required and ultimately no longer be required.

\subsection{DOCTRINE PRAYER APPLICATION GAFATAR}

GAFATAR Doctrine states that had it been praying applications, ie practicing the teachings of prayer in daily life, keep away from indecency and evil, then, the prayer ritual does not need to be implemented. This provision is an opinion that is not fundamental, because prayer is an obligation for all believers, since the revelation of the command to run the prayer, until the end of time, provided a predetermined time, as the word Allah in Sura. An-Nisa: 103.

\section{Authority's interpretation of the Qur'an and the Bible Other}

In a meeting between MUI, FKUB, State Attorney, Resot Cilacap Police, Ministry of Religion and PAKEM Cilacap on March 22, 2011, Chairman KOMAR, Mr. Sudarno said that in KOMAR, anyone can learn together, understand and interpret even the contents of the Qur'an. At the meeting there was an impression that every member of KOMAR could have made interpretation of the meaning and content of the Qur'an, to understand its contents, even without the provision of adequate knowledge. This is also the principle GAFATAR flow.

Keep in mind that the Quran, a good dose of Arabain language, has a literature that cannot be matched by anyone, and it is one of the main miracles of the Quran. Lack of knowledge of Arabic course, they can be led to the shifting of meaning and understanding of what is implied in the verses of the Koran, especially those who do not master the Arabic language.

To interpret Al-Qu'an, at least there are some requirements that must be met. And if someone was not met these requirements, then it is not justified to interpret the Koran ". The statement in principle wis viewed as not "a decision that an absolute requirement, but it is a decision that surveillance is solely to keep the brutal attitude of humans in interpreting the Koran". It is said that the decision is not absolute, because the conditions are not the provisions of Allah and His Messenger, but the terms of the provisions made by the man himself. 
These requirements, according to Sheikh Ali Ashobuny in Kitab At-Tibyan Fii Ulumil Qur'an mentioned that "science must be owned completely by a mufassir", at least are: (1) Arabic, Nahwu, Sharaf and sciences balaghah, (2) Science Usul Fiqh, (3) Science of Tawheed, (4) Science Asbabu An-Nuzul and Qiyas, (5) Science Nasikh wa Mansukh, (6) the hadiths that explain the intent pronunciations mujmal and mubham, (7) Al-Mauhibah Science (knowledge of God to someone who inherited their knowledge and clean hearts from worldly takabbur and hubbun).

Thus, to interpret understand the contents of the Qur'an, so as not to deviate from the meaning, there must be a teacher / teacher, or those who have knowledge of the sciences mentioned above.

About Five Time Prayer and Fasting Romadlon that are not obligatory

The notion that prayer, zakat, fasting and Hajj for Muslims is not mandatory, because at this time in our country is still in a state of darkness (dzulumat), also suggested that the teachings of Islam is not perfect, so that one day, if it is perfect, liability law that has just been implemented.

GAFATAR teachings like this is something that is not fundamental, because, with the revelation of the Qur'an. Al Maidah (3): 3)

Meaning: "This day I have perfected for you your religion, and have chosen for ni'mat both ends unto me, and have chosen for you Islâm as your religion"

About how Muslims should run worship Allah al-Qur'an Surat al-Anfal (9) of paragraph 11, said:

فإن تابو ا و أقامو ا الصلاة و آتوا الزكاة فإخو انكم في الدين ونفصل الآيات لقوم يعلمون

Translation: "If they repent, establish prayer and give zakah, then (they) are your brothers in religion. And we explain the revelations for a people who know. "Then the Prophet Muhammad, also confirmed in the hadith him.

"Rasulullah SAW said: Islam is built on five cases: testify that in fact there is no god but Allah and the Prophet Muhammad, establish prayer, pay Zakat, Hajj and fasting Ramadan."

Under the provisions of the Koran and the Hadith, will not drop any command from Allah SWT related to Shari'ah, and commands prayer, zakat, fasting and Hajj is obligatory for the Muslims, legally binding since the order handed down to Rosululloh SAW, until the end of time.

\section{CLOSING}

The existence of a cult in Indonesia is not something new in the social and spiritual life. An understanding of this kind occurred in all the religions of the world, even its existence has happened thousands of years ago from the time of the companions of the Prophet Muhammad.

GAFATAR previously declared itself as a social movement is believed to be a continuation of the flow of al-Qiyadah al-Islamiyah founded by Ahmad Mushadeq that by MUI Fatwa declared heretical misleading. Although, it was admitted based on Islam and Pancasila as the basis of the organization, GAFATAR actually developed the doctrine that deviate from Islamic shariah.

MUI at the Working Meeting has issued a decree on 10 criteria Cult, namely: (1) deny one of the pillars of faith and the pillars of Islam, (2) believe in or follow the aqidah is not in accordance with the Qur'an and the Sunnah; (3) believe the revelation after the Koran, (4) the authenticity or truth of the Koran, (5) make the interpretation of the Koran that are not based on the rules of interpretation, (6) not recognizing the Hadith as a source of Islamic teachings, (7) abusive, harassing or demeaning the prophets and apostles, (8) to deny the Prophet Muhammad as a prophet and the last messenger, (9) change, add to or reduce the points of worship that have been, and are set by the shariah, such as Haj is not to the House, not obligatory prayers five times, (10) mengkafirkan fellow Muslims without the proposition syar'i as infidel Muslims simply because it was not his group.

Based on these criteria MUI Fatwa Number 06 Year 2016 concerning flow movement Fajar Nusantara (GAFATAR) on February 3, 2016, provides: First, the flow GAFATAR (Gerakan Fajar Nusantara) is a religious sect that puts Ahmad Moshaddeq as a spiritual teacher as to believe and teach the doctrine among others; (I) the carrier treatise of God Almighty, as the messiah and savior, namely Ahmad Moshaddeq alias Abdus Salam Messi is essentially a prophet after the Prophet Muhammad; (Ii) do not require the five daily prayers, fasting Ramadan, and pilgrimage. Second, the flow GAFATAR is misguided and misleading, because: a metamorphosis of the flow of al-Qiyadah al-Islamiyah already difatwakan astray through the MUI Fatwa Number 04 Year 2007 and teaches understanding and confidence Millah Abraham, that is lost is misleading because it confuses the teachings of Islam, Christianity, and Jews to interpret the verses of the Koran that do not correspond with the tafsir. Third, scholars, government and society have to participate in coaching, training, and supervision of administrators, followers and sympathizers of the former GAFATAR to return to the correct Aqeedah. 
Fajar Nusantara Movement (Gafatar) Heresy in The Perspective of Indonesian Ulema Council (Mui)

\section{SOURCES OF FUNDING}

This research received no specific grant from any funding agency in the public, commercial, or not-for-profit sectors.

\section{CONFLICT OF INTEREST}

The author have declared that no competing interests exist.

\section{ACKNOWLEDGMENT}

None.

\section{REFERENCES}

[1] Ajaran Sesat Millah Ibrahim atau Milah Abraham, https://www.facebook.com/DatoSahol/posts/10152038799304596, diakses 5 Pebruari 2016

[2] Departemen Agama RI, Al-Qur'an dan Terjemahannya, Surabaya: Penerbit Mahkota, 1989.

[3] Djamaluddin, M. Amin, "Proses Lahirnya Gafatar (gerakan fajar Nusantara), http://www.lppipusat.com/proses-lahirnya-gafatar-gerakan-fajar-nusantara.html., diakses 3 Pebruari 2016.

[4] Effendi, Farid Zainal, "Aliran-Aliran dalam Islam", www.pascasarjanaumj.org/file/FZE-Aliranaliran\%20Islam.pdf, diakses 4 Pebruari 2016

[5] Fatwa MUI No. 04 Tahun 2007 Tentang Aliran Al-Qiyadah Al-Islamiyah, https://asfuriahmad.wordpress.com/fatwa-mui-no-04-tahun-2007-tentang-aliran-al-qiyadah-al-islamiyah/ Diakses 5 Pebruari 2016

[6] Fenomena Aliran Sesat di Indonesia, dalam Ikhlas Beramal, No. 61 Tahun XIII, Maret 2010

[7] Gafatar Adalah Penjelmaan Al-Qiyadah Al-Islamiyah Yang Dilarang, http://www.beritasatu.com/nasional/343669-gafatar-adalah-penjelman-al-qiyadah-al-islamiyah.html, Diakses 1 Pebruari 2016

[8] Hadziq, Abdullah, Diktat Kuliyah: Pendekatan dalam Pengkajian Islam, Surakarta: Universitas Nahdlatul Ulama Surakarta, tth.

[9] Harahab, Yulkarnain., dkk., "Aliran Sesat dalam Perspektif Hukum Pidana Islam dan Hukum Pidana Nasional”, Mimbar Hukum Vol. 20, No. 3, Oktober 2008

[10] Hidayatulloh, Moh. Taufick "Mengupas Beberapa Ajaran Komunitas Millah Abraham (Komar) Yang Cenderung Menyimpang Dari Ajaran Agama Islam”, Makalah disampaikan pada diskusi Menyikapi Berkembangnya Aliran Komunitas Millah Abraham (KOMAR), yang dilaksanakan di Kantor Kementrian Agama Kabupaten Cilacap, Tanggal 29 Maret 2011

[11] Hilmi, Irfan, "Kajian Kriteria Aliran Sesat”, dalam http://binbaz.atturots.or.id/berita-inilah-tausiyah-ustadzirfan-hilmi-mui-pusat-di-icbb.html\#ixzz3R, diakses 3 Pebruari 2016

[12] http://abumuslimsalafi.multiply.com/journal/item/301. Didownload Tanggal 28 Januari 2016

[13] http://aceh.tribunnews.com/2015/01/08/diduga-aliran-sesat-kantor-gafatar-digerebeg-warga.html, diakses 5 Pebruari 2016

[14] http://antarabogor.com/berita/3353/sebanyak-1800-orang-ikut-napak-tilas-karawang-bekasi, diakses 9 Pebruari 2016

[15] http://batam.tribunnews.com/2012/05/06/gerakan-fajar-nusantara-gelar-donor-darah-di-plaza--botania, diakses 9 Pebruari 2016

[16] http://gafatar.org/component/content/article/88-slideshow/83-tentang-kami.html?itemid=435, diakses 9 Pebruari 2016

[17] http://gafatar.org/profil-gafatar/struktur/pengurus-dpp/88-slideshow/142-dasar-pemikiran-berdirinyagafatar.html., diakses 9 Pebruari 2016

[18] http://nasional.news.viva.co.id/news/read/721725-ini-cara-gafatar-rekrut-pengikut.html, $\quad$ diakses 5 Pebruari 2016 
[19] http://news.detik.com/berita/3116034/gafatar-pernah-daftar-ke-mendagri-tapi-ditolak-karena-terkaitnii.html, diakses 5 Pebruari 2016

[20] http://news.detik.com/berita/3116034/gafatar-pernah-daftar-ke-mendagri-tapi-ditolak-karena-terkaitnii.html, diakses 5 Pebruari 2016

[21] http://news.liputan6.com/read/394680/dianggap-sesat-deklarasi-ormas-bubar.html., diakses 9 Pebruari 2016;

[22] http://pkspiyungan-org.blogspot.co.id/2016/01/mereka-hilang-karena-ikut-gafatar-apa.html, diakses 10 Pebruari 2016

[23] http://tokohpenemu.blogspot.com/2016/01/mahful-muis-tumanurung-ketum-gafatar.html, diakses 4 Pebruari 2016 13:42. Lihat juga http://gafatar.org/item/77-mahful-tumanurung-gafatar-bukan-organisasikeagamaan.html., diakses 9 Pebruari 2016

[24] http://urantia-indonesia.tripod.com/galeri/ritual.htm. Didownload Tanggal 28 Januari 2016

[25] http://usupress.usu.ac.id/files/Dalili--alil\%20Al\%20Qur\%27an\%20tentang\%20Shalat_Final_ bab \%201. Pdf. Didownload Tanggal 28 Januari 2016

[26] http://www.antara.co.id/arc/2007/10/25/depag-teliti-aliran-al-qiyadah-al-islamiyah/

[27] http://www.beritasatu.com/343670-gafatar-adalah-penjelamaan-al-qiyadah-al-islamiyah-yangdilarang.html., diakses 5 Pebruari 2016

[28] http://www.beritasatu.com/nasional/343672/mengapa-banyak-anggota-gafatar-hijrah-kekalimantan.html., diakses 2 Pebruari 2016

[29] http://www.beritasatu.com/nasional/343673-gafatar-ingin-membentuk-agama-baru.html., diakses 2 Pebruari 2016

[30] http://www.beritasatu.com/nasional/343673-kenapa-banyak-anggota-gafatar-hikrah-ke-kalimantan, diakses 2 Pebruari 2016

[31] http://www.merdeka.com/peristiwa/gafatar-organisasi-terlarang-seperti-nii.html, diakses 5 Pebruari 2016

[32] Kisi-kisi Materi Ajaran KOMAR. Untuk kalangan terbatas. Bandung: al-Qiyadah al-Islamiyah, tth

[33] Koharuddin, Nasrul, Ahmad Mushaddeq dan Ajaran Al-Qiyadah Al-Islamiyah, Yogyakarta: Media Pressindo, 2008

[34] Mengenal Mahful Muis Tumanurung: Ketua Umum Organisasi Gafatar, http://www.aktualita.co/tag/mahfudmuis-tumanurung, diakses 2 Pebruari 2016

[35] Mukti, Widya, Menilik Ajaran Sesat Menuju Pemahaman Spiritual, Yogyakarta: Tajidu Press, 2008;

[36] Nasution, Harun, Teologi Islam, Aliran-Aliran, Sejarah Analisa Perbandingan, Jakarta: UI Press, 1986

[37] Pranowo, Sigit, "Sepuluh Kriteria Aliran Sesat", http://www.eramuslim.com/ustadz-menjawab/aqidah/10kriteria-aliran-sesat.htm., Diakses 3 Pebruari 2016.

[38] Sejarah Lahirnya Gafatar: dari Mushadeq ke Mushadeq Lagi, hht://nasional.tempo.co/read/news/2016/01/14/173735906/sejarah-lahirnya-gafatar-dari-musyadeqke-musyadeq-lagi,diakses 6 Pebruari 2016

[39] Shiddieqy, T.M. Hasbi Ash-. Ilmu-ilmu Al-Quran, Jakarta: Penerbit Al-Qur'an, 1972

[40] Sibuea, Hariis Y.P., "Perspektif Yuridis Penanganan Organisasi Masyarakat Gafatar", Info Singkat Hukum Vol. VIII, No. 02/II/P3DI/Januari/2016

[41] Su'aidi, Qomar, Agar Tidak Menjadi Muslim Liberal, Jakarta: Pustaka Qaulan Sadida, 2008.

[42] Suara Pembaharuan, Selasa 19 Januari 2016

[43] Suyuthi, Syaikh Jalaluddin As-, Lubannuqul fii asbaabunnuzul, Terj. R. Abdul Mujib, Riwayat Turunnya AyatAyat Suci Al-Qur'an, Surabaya: Mahkota, tth.

[44] Syaikh Jalaluddin Assuyuthi, Lubannuqul fii asbaabunnuzul, Terj. R. Abdul Mujib, Riwayat Turunnya AyatAyat Suci Al-Qur'an, Mahkota, Surabaya, halaman 622-624. Lihat juga: Departemen Agama RI, Op. Cit... Halaman 988.

[45] Zara, M. Yuanda., dkk, Aliran-Aliran Sesat di Indonesia, Yogyakarta: Banyu Media, 2007. 